\title{
VALMISTAUTUMINEN JATKUVAAN MUUTOKSEEN
}

Kvalifikaation sekä pätevyyden käsitteiden laajempi käyttöönotto ja -tutkimuksen kansainvälinen läpimurto liittyvät 60- ja 70-lukujen länsimaissa virinneeseen koulutus- ja oppimismuotojen uudistamiseen. Kvalifikaation käsite (samoin kuin pätevyydenkin) viittaa yhteiskunnallisesti välttämättömien toimintavalmiuksien muotoutumiseen oppimisen kautta sekä näiden oppimistulosten byödyntämiseen tilanteissa, joissa yksilöt joutuvat kobtaamaan ybteiskunnallisen muutoksen mukanaan tuomia taloudellisia, teknologisia, ammatillisia tai kulttuurisia vaatimuksia ja odotuksia.

Pätevyys- tai kvalifikaatiovaatimusten määrittelyssä ovat korostuneet yleisesti seuraavat lähtökohdat:

a) ne ovat sidoksissa yhteiskunnalliseen muutokseen tai kehittymiseen,

b) ne ovat jatkuvasti muuttuvia ja yhteydessä erilaisiin yhteiskunnallisiin odotuksiin,

c) ne ovat luonteeltaan inhimillisen toiminnan tai aktiviteetin kuvausta, ja

d) ne muotoutuvat oppimisen ja siihen perustuvan soveltamisen kautta.

Erään keskeisen ongelman kvalifikaatioiden tai pätevyyksien määrittelyssä muodostaa käsitteiden laajuus ja epämääräisyys. Kysymys on yksilölle tai tietylle ryhmälle asettuvista laadullisista toimintaan liittyvistä vaatimuksista tai odotuksista, esimerkiksi työtehtävien tehokkaaseen hoitamiseen liittyvästä ammattitaidosta. Mutta ongelmana on ollut se, millä tasolla ja millaista kuvausjärjestelmää näiden vaatimusten esittämisessä noudatetaan. Kansainvälisessä kirjallisuudessa erityisesti tulevaisuuden pätevyysvaatimuksia on määritelty kolmesta erilaisesta lähtökohdasta käsin.
Ensinnäkin kvalifikaatioiden määrittelyä on tehty niistä yhteiskunnallisista toiminnoista tai työtehtävistä käsin, jotka pitää hallita yhteiskunnassa ja/tai työelämässä. On pyritty määrittelemään sellaisia yleisiä elämän- ja ammattitoiminnan tietoja/taitoja, joita tarvitaan menestymiseen nykypäivän tai tulevaisuuden nopeasti muuttuvassa maailmassa.

Toinen lähestymistapa on pyrkinyt selvittämään niitä psykologisia persoonallisuustekijöitä, joiden avulla yksilöt jäsentävät itseään ja ympäristöään. Tällaisia yksittäisiä tekijöitä ovat esimerkiksi erilaiset asenteet, maailmankuva, luovuus, itseluottamus jne.

Kolmas yleisesti käytetty lähestymistapa kvalifikaatioiden määrittelyssä on ollut yksilön sosiaalis-kulttuurisen ympäristön ja siihen liittyvien erilaisten intressiryhmien tai viiteryhmien, joskus ristiriitaistenkin arvojen, vaatimusten ja tarpeiden selvittäminen. Elinympäristössämme, samoin kuin työpaikoillammekin, on useita näkymättömiä arvoja tai toimintatapoja, jotka meidän tulee hallita pystyäksemme toimimaan riittävän tehokkaasti tai tarkoituksenmukaisesti. Nämä näkymättömät tai piilevät arvot voivat vaihdella asuinpaikan, kulttuurin, työpaikan mukaan ja kohdistuvat eri tavalla esimerkiksi eri asemassa tai sukupuolta oleviin ihmisiin.

Edellisen perusteella yksilön tulevaisuuden pätevyysvaatimukset voidaan yleisesti määritellä niiksi tiedoiksi, taidoiksi, asenteiksi ja henkilökohtaisiksi ominaisuuksiksi, jotka mahdollistavat yksilöiden mielekkään ja tasapainoisen elämisen sekä kehittymisen niin sosiaalis-kultturaalisessa elinympäristössään kuin työympäristössäänkin. Se, millaisia yksityiskohtaisempia tai konkreettisempia pätevyysvaatimuksia tule- 
vaisuuden elämänhallinnalle asetetaan, on riippuvainen siitä, millainen käsitys meillä on tulevasta yhteiskunnasta.

\section{Eräitä mahdollisia tulevan yhteiskunnan peruspiirteitä}

Maailma on muuttunut ja työ on muuttumassa. Tällä hetkellä elämme ehkä historiamme voimakkainta muutoksen aikakautta, jossa yhteiskuntamme taloudelliset rakenteet, yhteiskunnalliset instituutiot ja myös yksilöiden elämäntyylit ja arvot ovat muuttumassa. Tämä muutos on ehkä syvällisempi kuin osaamme vielä kuvitellakaan. Voidaan osittain perustellusti väittää, että koko maailmankuvamme on muuttumassa. Perinteinen newtonilainen maailmankuva, jonka mukaan kehitystä on tähän asti tarkasteltu, on asetettu kyseenalaiseksi. Oletukset asioidentilan staattisuudesta ja muutosten minimaalisuudesta, suoraviivaisuudesta ja pitkälle ennustettavuudesta ei näytä pitävän enää paikkaansa, mikäli tarkastellaan Euroopassa ja Suomessa parin viime vuoden aikana tapahtunutta yhteiskunnallista ja kulttuurista muutosta. Muutosten ennustamattomuus, satunnaisuus ja yllättyvyys ovat piirteitä, joilla käynnissä olevaa yhteiskunnallista murrosta voidaan pikemminkin kuvata.

Olemmeko siirtymässä sellaiseen yhteiskunnalliseen tilanteeseen, kuten ns. postmodernit käsitykset antavat ymmärtää, jossa yhteiskunnallinen muutos on jatkuvaa ja ennalta-arvaamatonta? Joka tapauksessa yhteiskunnassa tapahtuvat muutokset ovat luonteeltaan kokonaisvaltaisia, ne kattavat kaikki inhimillisen elämän alueet ja nämä elämänalueet liittyvät entistä tiiviimmin toisiinsa.

Toisaalta yhteiskunnassa tapahtuva muutos on selvästi ristiriitaista. Keskushallinnon ja muiden sosiaalisten institutionaalisten kokonaisjärjestelmien hajoittaminen osajärjestelmiksi, joista esimerkkinä on Suomessa keskushallinnon voimakas purkaminen ja alueellisen päätäntävallan lisääminen, teknologian lisääntyvä käyttöönotto, tiedon lisääntyminen ja sen epätasaiset käyttömahdollisuudet sekä talouden ja teknologian entistä tiiviimpi liittyminen toisiinsa luo erilaisia jopa vastakkaisia kehityssuuntia, jännitteitä ja ristiriitoja.
Yksilön kannalta oleellista on se, että elinympäristön hallinta on muuttumassa entistä kompleksisemmaksi ja vaikeammaksi. Arkipäivän toiminnoissa jokainen henkilö tarvitsee uusia teknisiä taitoja ja entistä laajempia tietoja. Ollakseen terveitä ja tehokkaita yhteiskunnan jäsenten on itse asiassa pakko omaksua uudentyyppinen käyttäytymistaitojen verkosto, jota on kutsuttu myös elämäntaitojen verkostoksi.

Muutosten lineaarisuuden katoaminen merkitsee myös ajattelumallien lineaarisen muutoksen riittämättömyyttä. Asiat on nähtävä uudesta näkökulmasta. Esimerkkejä tämänsuuntaisesta tarpeesta on myös Suomessa paljon. Mitä ajattelee maailmasta esimerkiksi valtion virkamies tai maanviljelijä, joka huomaa työpaikkansa tai elinkeinonsa olevan vaarassa vuosisataisten perinteiden ja hitaan lineaarisen, ennustettavissa olleen kehityksen jälkeen.

Toinen keskeinen, osittain jo havaittavissa oleva kehitystrendi on arvojen ja arvoperusteiden muuttuminen ja heterogenisoituminen. Olemme keskellä kansainvälistä informaatiotulvaa ja muuttoliikettä, joka tarjoaa toisaalta virikkeitä oman kulttuurin kehittämiselle, mutta toisaalta voi hävittää kansallisen identiteetin tai kulttuurin. Virikkeiden runsaudesta johtuen henkilöt omaksuvat erilaisia mielipiteitä ja arvoja ja yhteiset perinteiset toimintamallit differoituvat erilaisiksi alakulttuureiksi. Vastaanottamamme ja käyttämämme informaatio on myös entistä muuttuvampaa, atomistisempaa ja se vanhenee entistä nopeammin. Samalla tämä informaatio on käyttöarvoltaan entistä suhteellisempaa: samalla informaatiolla tai tiedolla on paljon merkitystä toisille ihmisille, mutta toisille suhteellisen vähän.

On ilmeistä, että yllä kuvatut muutosprosessit tullevat edelleen jatkumaan ja entisestäänkin kiihtymään kansainvälisen vuorovaikutuksen ja kilpailun lisääntyessä sekä tutkimus-, tuotantoja koulutusyhteistyön laajentuessa.

\section{Teesejä tulevaisuuden pätevyysvaatimuksiksi}

Edellä esitetyt yhteiskunnallisen muutoksen näkökulmat lähtökohtana pyrin tarkastelemaan teesien muodossa, mitä seurauksia tällä nykyään on yksilöiden tulevaisuuden kvalifikaatioihin tai 
pätevyysvaatimuksiin. On muistettava kuitenkin, että mikään muutos tai yhteiskunnallinen kehittyminen ei ole determististä, vaan siihen voidaan aina vaikuttaa, ja mikään ei ole niin vaikeaa kuin tulevaisuuden ennustaminen nykyaikana.

1. Ensimmäinen väitteeni on, että jatkuvien muutosten aiheuttamien kriisien ratkaisemiseksi yksilön on tulevaisuudessa pystyttävä orientoitumaan uudella tavalla itseensä ja ympäristöönsä. Tämä edellyttää kykyä ja taitoa maailmankuvan jatkuvaan uudelleenjäsentämiseen, jatkuvaa ja elinikäistä oppimista. Keskeinen vaatimus tulevaisuuden kansalaiselle on omata taidot, joiden avulla voi käynnistää ja ylläpitää oppimisprosessiaan muutosten paineissa. Esimerkiksi Ulrich Beck kirjassaan Riskiyhteiskunta kuvaa oppimista "pakkona", joka ei voi suuntautua enää vain menneisyyden tai nykyisyyden hallintaan, vaan jonka on suuntauduttava myös erilaisten intuitiivisten tai heurististen tulevaisuuskuvien 'ennaltaelämisen' harjoitteluun.

2. Toinen väitteeni on se, että tulevaisuuden henkilön pitää hallita käytännöllis-teoreettiset ongelmanratkaisu- ja ajatteluvalmiudet. Tulevaisuus tuonee mukanaan entistä kompleksisemmat työ- ja elinympäristöt ja samalla jatkuvan tarpeen hyvinkoulutetuista, osaavista työntekijöistä ja aktiivisista kansalaisista. Se mikä muutama vuosikymmen oli tarpeen vain hyvinkoulutetulle eliitille, on nyt olennaista kaikille. Ajattelu, ymmärtäminen, osaaminen ja ongelmanratkaisu ovat tulevaisuuden keskeisiä vaatimuksia niin työpaikalla kuin arkipäivän elämässäkin. Ongelmanratkaisua voidaan pitää esimerkkinä sellaisesta ajattelutoiminnasta, jolle on tyypillistä asiantilojen uudelleenjäsentäminen.

Ongelmanratkaisutaitoja ei pidä nähdä taitoina sinänsä, vaan sen on liityttävä kiinteästi käytännön toimintaan, kykyyn soveltaa tietoja erilaisiin käytännön tilanteisiin niin työpaikalla kuin muussakin elämässä. Näin ollen näihin taitoihin liittyy olennaisesti tiedon hankinnan ja käytön valmiudet sekä entistä suurempien ja monimutkaisempien syy-seuraus suhteiden ymmärtämisen vaatimukset. Esimerkiksi useissa työelämän pätevyysvaatimuksia selvittäneissä tutkimuksissa ongelmanratkaisu- ja soveltamiskykyä pidetään keskeisimpänä pätevän työntekijän tunnuspiirteenä. Edelleen, kun on tutkittu ammattitaidon kehittymistä, esimerkiksi noviisista ekspertiksi, on havaittu tiedon käyttötapojen ja ongelmanratkaisukyvyn kehittäminen edellytykseksi hyvän ammattitaidon kehittämiselle ja säilyttämiselle.

Myöskin oppimisprosessin jatkuvuutta voidaan parhaiten ylläpitää totuttamalla ja kasvattamalla yksilöt ongelmanratkaisijoiksi, joille oppiminen on resurssi, jota on jatkuvasti käytettävä.

3. Kolmas väitteeni on se, että tulevaisuudessa tarvitaan entistä enemmän keskeisten perustietojen tai -taitojen hallintaa. Useissa aikuiskasvatuksen alueen tutkimuksissa on päädytty siihen, että niin työelämässä kuin elämässä yleensä selviytymisen tai menestymisen keskeinen este on perustietojen tai -taitojen puuttuminen. Perustiedoissa olevat 'aukot' tai väärinymmärrykset haittaavat kasautuessaan uusien taitojen omaksumista sekä rajoittavat muiden kykyjen tai tietojen suuntautumista ja soveltamista. Esimerkiksi työelämän muuttumisen analysoinnin yhteydessä on tulevaisuuden vaatimukseksi asetettu poikkeuksetta laaja-alainen ja joustava, dynaaminen ammattitaito. Laaja-alaisuutta tai joustavuutta ei voida enää ajatella, kuten 60- ja 70-luvuilla tehtiin, yksittäisten tai atomististen tehtävien osaamisen summana, vaan tällä hetkellä laaja-alaisuus ja joustavuus tulee käsittää ammatillisten perustietojen ja -taitojen soveltamisena erilaisiin työtehtäviin, -välineisiin ja -organisaatioihin.

On ilmeistä, että myös sivistynyt kansalaisuus, samoin kuin tehokas työtoimintakin, vaatii monipuolista ajattelua ja osaamista, jota on mahdollista tuottaa vain panostamalla perustietojen/taitojen hallintaan.

4. Neljäs tulevaisuuden vaatimuksia koskeva väitteeni on se, että tulevaisuuden vaatimusten kohtaaminen edellyttää kansalaisilta aktiivisuutta, entistä suurempaa yksilöllistä vastuunottoa omasta toiminnastaan ja kehittymisestään, itseohjautuvuutta tai -suunnittelua sekä positiivista minäkäsitystä ja itseluottamusta. Nämä persoonallisuuden laadulliset piirteet ovat 
keskeisiä, jotta yksilö pystyy toiminaan tavoitteellisesti ja tekemään toimintaansa koskevia päätöksiä näihin tavoitteisiin pyrkiessään. Edelleen taloudellisen tilanteen mahdollisesti käydessä epävakaiseksi sekä erilaisten sosiaalisten instituutioiden ohjauksen murentuessa kansalaiset joutuvat ottamaan enemmän aktiivista vastuuta omasta toiminnastaan kaikilla elämän alueilla. Myös työelämän muuttuvat laadulliset vaatimukset edellyttävät työntekijöiltä entistä suurempaa itseohjautuvuutta, päätöksentekokykyä ja vastuuntuntoa työtehtävien hoidossa.

Toisaalta kehittyäkseen oman elämänsä 'omistajaksi' ja vastuulliseksi itsensä kehittäjäksi yksilön on kehityttävä itsenäiseksi persoonaksi, jolle on luonteenomaista vastuuntunto ja positiivinen minäkuva. Ilman positiivista minäkuvaa ja kehittynyttä 'persoonallisuutta' ei jatkuva oppiminen tai itsensä kehittäminen ole palkitsevaa tai mielekästä.

5. Viides tulevaisuuden pätevyysvaatimuksia koskeva väitteeni on se, että tulevaisuudessa yksilöiltä edellytetään kokonaisvaltaista ja arvosidonnaista maailmankuvaa. Ilman kokonaisvaltaista käsitystä itsestään ja ympäristöstään ihmisen on vaikeaa, osittain mahdotontakin suhteuttaa itseään työ- tai muuhun toimintaympäristöön. Vaarana on juurettomuus, jossa toisaalta ei pystytä hyödyntämään oman kansallisen kulttuurin keskeisiä parhaita puolia elävästi ja toisaalta torjutaan muiden kulttuurien virikkeet oman heikosti kehittyneen identiteetin menettämisen pelosta. Seurauksena tästä kehityksestä voi olla suvaitsevaisuuden ja erilaisuuden sietämisen sekä aktiivisen sivistyksellisen uteliaisuuden kehittymisen estyminen.

Toisaalta kokonaisvaltaisen arvoperustaisen maailmankuvan puuttuminen ehkäisee yksilöllisten ja myös yhteisöllisten mielekkäiden kehittämistavoitteiden, perspektiivien, asettamisen, josta seurauksena on mahdollisuuksien heikkeneminen osallistua aktiiviin kansalaistoimintaan.

6. Kuudes väitteeni on se, että tulevaisuudessa yhteiskunnan toimintojen ja työtehtävien kansainvälistyessä, siirryttäessä enemmän informaation siirtoon ja käyttöön tarvitaan entistä laajempia teknisiä ja verbaalisia yhteistyötaitoja.
Automaattisen tiedonkäsittelyn oletetaan tulevan osaksi jokapäiväistä elämää ja työtoimintaa. Kansainvälinen yhteistyö edellyttää vieraiden kielten taitoja sekä kulttuurillisten ja muiden symbolien merkitysten ymmärtämistä. Myöskin työtehtävien ennustetaan tulevaisuudessa entistä enemmän nivoutuvan toisiinsa projekti- tai verkkoperiaatteella, jolloin ammattitaidon olennaisen osan muodostavat juuri erilaiset yhteistyötaidot. Esimerkiksi amerikkalaisissa tutkimuksissa on jo nyt todettu ns. perusinsinöörin työtehtävistä noin 70-75 prosenttia olevan yhteistyötä muiden henkilöiden kanssa.

\section{Mitä seurauksia?}

Yhteiskunnassa tapahtuvien muutosten olemusta ja syitä ei ole analysoitu kasvatustieteellisestä eikä aikuiskoulutuksen näkökulmasta riittävästi, mutta jo pinnallisetkin havainnot osoittavat sen, että joudumme pohtimaan millaisilla oppimis- tai koulutusstrategioilla vastaamme tulevaisuuden haasteisiin.

Riittävien yleissivistävien ja ammatillisten perusvalmiuksien sekä ajattelu- ja ongelmanratkaisuvalmiuksien antaminen edellyttää radikaalia muutosta nykyisissä perusasteen koulujen opetussuunnitelmissa ja työtavoissa. Kysymys on siitä, kuinka tämä toteutetaan.

Tulevaisuudessa joudutaan pohtimaan myös sitä, mitkä tai millaiset koulutustehtävät ovat oleellisia aikuiskoulutuksen eri instituutioille. Kansalaisten tarpeiden eriytyessä tulisi vastata entistä useampiin ja samalla monimuotoisempiin ja yksilöllisempiin haasteisiin. Millaisia toimintatapoja tämä edellyttää? Kuinka oppilaitokset pystyvät avaamaan vaihtoehtoisia tapoja ihmisille organisoida uudelleen ja jatkuvasti omaa henkilökohtaista elämäänsä tai millä ehdoilla pystytään antamaan riittävä arvoperustainen maailmankuva tulevaisuuden yksilöllisen kehityksen varmistamiseksi?

On myös ilmeistä, että työelämässä joudutaan pohtimaan nykyiset ammattipätevyydet uudelta - ajattelun ja toiminnan synteesin - perustalta. Edelleen kun oppimisen on tultava keskeiseksi osaksi ihmisen jokapäiväistä elämää, joudutaan pohtimaan, miten oppiminen sisällytetään osaksi työtehtäviä tai osaksi luonnollista työympäristöä. Mitä edellä mainittu merkitsee ammatillisen aikuiskoulutuksen eri toimintamuotojen kehittämiselle, pedagogisille ja didaktisille kehittelyille? 